\title{
THE BEGGAR'S OPERA AND ITS COMPOSERS
}

What is the secret of the success of the Beggar's Opera? Who could have believed that a pasticcio of tunes scattered through a libretto of no outstanding merit, which created a furore two hundred years ago, would bear revival? And yet the fact remains that the revived Beggar's Opera, produced by Mr. Nigel Playfair, at the Lyric Theatre, Hammersmith (London), on June 7, 1920, is still going strong in its continuous third year! Miss Nellie Chaplin, in Music and LetTers (July, 1922), thus writes:- "The unprecedented success of the Beggar's Opera is due to the old tunes, which are in our blood. Clever as Mr. Gay's libretto is, if Ir. Pepusch had written the tunes it would not have had the same hold on the public. We owe him a debt of gratitude. Even in the Overture, the only number he wrote, he took for his theme 'The Happy Clown,' and except a song by Purcell, a march by Handel, a snatch-song by Macheath, and Henry Carey's 'Sally in our Alley,' all is British folk-music, charmingly harmonised and orchestrated by Frederic Austin."

Now, inssmuch as Miss Chaplin's opinion is that of the average man in the street, I think it only fair to state that though " British folkmusic " is largely in evidence throughout the ballad-opera, it only constitutes one-third of the actual tunes. In all, there are 69 tunes; and of these there are only 23 that can be classed as " British," while the remaining 46 are Irish, Scotch, French, Italian, etc., 25 being by known composers.

I have no intention of discussing folk-music or folk-tanes, but I make bold to remark that a tune presupposes a cumposer; and quite a number of "folk-melodies" can be traced to their composers. Not long since a programme of John McCormack's contained an item, " 'I'm sitting on the stile, Mary '-Irish folk-melody," whereas this tune was composed by George A. Barker, of Dublin, in 1846! With a little indnstry many of the "British folk-tanes" conld be traced and, I have no doubt, a patient delver could anearth the originals of all the airs in the Beggar's Opera. However, such a task, to be done adequately, would need a good-sized volnme; and my

- Since this article was at press such a needed volnme has been written by Mr. Frank Kidson, published by the Cambridge University Press. 
present article is merely intended to deal with the 25 tunes by lmown composers.

Dr. Pepusch spread his net wide for the tunes he selected and, in addition to the folk-tunes, he drew on popular airs by Handel, Frescobaldi, Bononcini, Purcell, Clarke, Eccles, Carey, Barrett, Ramondon, Mouret, Geminiani, Wilford, Leveridge, Vanbrugh and Dogget. It may be more convenient to take the airs to which composers can legitimately be assigned in the order in which they occur in the ballad-opera. As I write, I have before me the 1729 musical edition of the Beggar's Opera, which had successively belonged to Kane O'Hara (author of Midas), George Ogle (1740-1814), and Herbert Hore; and a former owner, apparently Ogle, has obligingly supplied the names of some of the sources.

Airs II., LI. and LXVI. were composed by .Jeremiah Clarke, who wøs organist of St. Paul's Cathedral, London, from 1695 to his death in 1707, and was also joint organist of the Chapel Royal. Air II. (“"The Bouny Grey-ey'd Morn ") dates from 1695, and was introduced into The Fond Husband in 1698; while Air LI. (" Come, Sweet Lass "), the song of which dates from 1685 (The Compleat Academy), was printed by Playford, as "Greenwich Park," in 1698, in the Dancing Master. Both tunes, transcribed for the harpsichord, are attributed to Clarke in a MS. folio music book in the British Museum, circa 1704, among the Add. MSS. 22099 (see Cat. of MS. Music in Brit. Mus., by A. Hughes-Hughes, Vol. III., p. 112). Air LXVI. ("Why are my Eyes still Flowing") dates from 1690, and is printed by Durfey in his Pills (II., 199), the attribution of the tune to Clarke is a MS. flute book of circa 1708 in the B. Mus. (Add. MSS. 34204). Clarke's death was due to a self-inflicted wound, supposed to have been the result of an unrequited attachment.

Air IV., " Why is your faithful Slave disdain'd?" was composed by Bononcini, the rival of Handel, and part composer of Muzio Scevola (1721). He was popular in London from 1720 to 1732 , and then went to Paris and Venice. The music of this tune will be found in Playford's Musical Banquet (1688), and also in Durfey's Pills (III., 211).

Air V., " Of all the Simple Things we do," was probably composed by Thomas Dogget, the Irish actor, who introduced it into his musical play of The Country Wake in 1696. It was published in Durfey's Pills (I., 249) as " The Mouse Trap," but may have been an old folktnne. Dogget was an actor-musician who flourished 1680-1710, and is best remembered as the founder of " Dogget's Coat and Badge."

Air VI., "What shall I do to show how much I love her?" was composed by Henry Purcell and was sung in The Prophetess, or the History of Dioclesian, in 1690 . The words are said to be by Sir 
Charles Hanbury Williams. Purcell's music score was published in 1691. The song will be found in Durfey's Pills (IV., 285), and is included as Purcell's in Kidson's Minstrelsy of England.

Air XI., "A Soldier and a Sailor," was composed by John Eccles for the song in Congreve's Love for Love, in 1696. Eccles was a good English composer and was Master of the King's Band from 1700 to 1735. The attribution of this tune to him is recorded in Add. MSS., B. Mus., 22,009, fol. 5.*

Air XV., "Pray, Fair One, be Kind," was composed by Richard Leveridge for a song sung by Wilks in the comedy of The Recruiting Officer, in 1706. Professor Swaen says that " if the song was actually sung in Farquhar's play it must have been an extra "; but, as a fact, it was sung in the original production and will be found in the original quarto (see William Archer's note in Farquhar's. Plays, Mermaid Series). Leveridge was a fine bass singer as well as composer, and his "All in the Downs" and "The Roast Beef of Old England " are well known. He sang from 1694 to 1734, and died on March 22, 1758.

Air XX., "March in Rinaldo," was composed by Handel, and occurs in his opera of Rinaldo, which was prodaced on February 24, 1711, at the Haymarket. This march was for long popular and was adopted by the Grenadier Guards.

Air XXII., "Cotillon." This French dance-tune was composed by Jean Joseph Mouret, and was frst danced in his Festes de Thalie, produced in Paris on August 14, 1714, being subsequently taken for a chorus in his Arlequin Tractant in 1716. The dance and tune then passed over to England and was in vogue as early as 1720 . It was printed as "Tony's Rant" in 1726. Mouret died at Charenton on December 22, 1738.

Air XXVIII., "Thus when the Sea was Roaring," is a song set to a tune by Handel, and which was introduced into Gay's What d'ye call it? in 1715. The music was printed as "The Faithful Maid, set by Mr. Handel," in the Musical Miscellany, 1729 (Vol. II. 94).

Air XXX., " How Happy are we," was composed by John Barrett in 1709, and published by Walsh in 1710. It was introduced into the Ladies' Fine Aires as "A Song, set by Mr. Barret." This English composer was born in 1674 and died in 1735 .

Air XXXI., "Of a Noble Race was Shenkin," was composed by Henry Purcell, and occurs in the Richmond Heiress, in 1693, as "Shenkin's Song to the Harp." The song, with music, was printed in Thesaunus Musicus (1698), and by Durfey (Pills, ח., 172), who also prints a second song to the same air.

"The B. Mus. MS. gives the title as "A Souldier and a Bailor-Eccles." 
Air XXXIV., "All in the Dorrns," was composed by Henry Carey, circa 1724, but was superseded by a tune of Leveridge's in 1729 (printed in the Village Opera in 1729). A variant of Carey's air was issued in sheet song form by Pietro Giuseppe Sandoni in 1730, a copy of which is in the British Museum $(G, 305)$.

Air XXXVII., to which no name is given, is a tune called " Constant Billy," printed in the 3rd Vol. of the Dancing Master, circa November, 1726, and somewhat earlier as a sheet-song, entitled, "When the Hills and Lofty Mountains." The tune, according to Sir Henry Bishop (in an article on "Old English Songs" in the Illustrated London News, 1851), was composed by Geminiani.

Air XXXIX., "The Irish Howl," was composed by George Vabbrugh, an English composer, in 1710, and was published in the Dancing Master, Vol. III., in November, 1726, and in the Merry Mountebank in 1732-a pseudo-Irish song-tune.

Air XLI., "If Love's a Sweet Passion," was composed by Henry Purcell and occurs in his Fairy Queen in 1692. Curiously enough, G. Calmus failed to identify it, while Professor Swaen imagined it to be the composition of Baildon, forgetful of the fact that Baildon was not born till 1727 .

Air L., "Would Fate to me Belinda give," was composed by an English actor-vocalist, John Wilford, in 1709, and was printed in 1710 , being subsequently included in the Musical Miscellany in 1729,

Air LV., " Ianthe the Lovely," was composed by John Barrett in 1701 and was printed in Playford's Duncing Master in 1716. Durfey prints it in his Pills (V., 300) as " set by Mr. John Barret."

Air LVIII., "Happy Groves," is also the composition of John Barrett, and is an adaptation of his song "The Pilgrim," dating from 1701. A copy of this song, with music " exactly engrav'd by T. Cross," is in the British Museum, dated 1705, with three reprints of subsequent date.

Air LIX., "Of all the Girls that are so Smart," was composed by Henry Carey in 1716. Carey also wrote the words, which, with the music, were printed in his Musical Century in 1740. Several ballads were written to this tune between the years 1725 and 1729 . Strange to say, this once popular tune was replaced by quite another melody about the year 1789 and still continues in vogue. A pleasant recollection of the present writer is having acted as accompanist for Sims Reeves in this song some 40 years ago.

Air LX., " Britons, Strike Home," was composed by Henry Purcell and occurs in Bonduca, 1695. Professor Swaen says that the air is in Purcell's King Arthur (1691), but this is a slip. It was very 
popular during the eighteenth century and was a great favourite with King George III.

Air LXIII., " Joy to great Cxsar," was in part composed by Frescobaldi (1583-1644), but was popularised by Michael Farinelli, and hence was known as "Farinelli's Ground," though it had also boen arranged by Lully in 1672. Durfey wrote a song entitled "The King's Health, set to Farinelli's Ground," in 1682, and the tone was printed in the Division Violin in 1684. In France the tune was known as "Follies d'Espagne," and was introduced into Telemaque.

Air LXVIII., " All you that must take a Leap in the Dark," was composed by Lewis Ramondon, a French singer who settled in London in 1705. About the year 1710 he essayed some song-tunes, which became popular, including the present one, published as a sheet-song in 1710. Durfey printed the tune as "A Hymn upon the Execution of Two Criminsls, by Mr. Ramondon," in his Pills (VI., 327).

W. H. Grattan Flood. 